and education concerning the relationship of the world's population to its material and cultural resources. The trustees of the Council are Frank $\mathrm{G}$. Boudreau, Detlev W. Bronk, Karl T. Compton, Frank W. Notestein, Frederick Osborn, Thomas Parran, John D. Rockefeller, III, and Lewis L. Strauss. The Council plans to study the problems of the increasing population of the world, to support research, and to make known the results of such research; it will also serve as a centre for the exchange of facts and information on population questions, and co-operate with individuals and institutions having similar interests. The Council does not intend to conduct research or educational activities with its own staff ; but it has already made a small number of research grants to universities and other established organizations, and has established a number of fellowships for the advanced training of students in the social and natural sciences at the predoctoral or postdoctoral levels. Approximately six fellowships, for study in the United States and elsewhere, will be offered during the academic year 1954-55, to be divided between students from the United States and from other countries. The basic stipend of 2,500 dollars a year may be supplemented to provide for maintenance of dependants and, especially in the case of foreign students, for travel or exceptional expenses. Preference will be given to candidates who are not more than forty years old. Application forms for these fellowships (to be returned before February 1, 1954) and further information can be obtained from the executive vice-president of the Council, Mr. Frederick Osborn, 230 Park Avenue, New York 17, N.Y.

\section{Eighth New Zealand Science Congress}

THE Royal Society of New Zealand holds triennially a New Zealand Science Congress, the purpose of which is to draw together for their mutual understanding the members of various scientific disciplines and to give the non-scientific public in New Zealand an opportunity of learning something of the status of science in the Dominion. The eighth such Congress will be held in Auckland during May 17-22, with excursions during May 23-24. The meeting will be divided between nine sections as follows : $(A)$ physical sciences; $(B)$ chemical sciences; $(C)$ botanical sciences; (D) zoological sciences; $(E)$ geological sciences; (F) geographical sciences; $(G)$ medical sciences ; $(H)$ social sciences; and $(J)$ anthropology. The sections are arranging symposia on various topics, but a noteworthy feature is that most of the symposia will be held jointly by two or more sections so that there will be a considerable cross-fertilization of ideas between workers in different branches of science. In fact, the keynote of the Congress is that the papers presented should promote the exchange of ideas and should not be highly specialized or technical. Consequently, the free movement of members between the various sections is encouraged, and, in general, the Congress is open to all, scientific or otherwise. The fee for membership is one guinea (10s. 6d. for students). Enrolment forms and further details can be obtained from the Honorary General Secretaries, Eighth New Zealand Science Congress, P.O. Box 9027, Auckland, S.E.1.

\section{National Science Foundation Awards}

THE National Science Foundation, Washington, D.C., has announced 123 awards totalling about $1,332,000$ dollars, these being the first group of awards to be made by the Foundation during the fiscal year 1954 for the support of basic research and related matters. The grants are made to institutions, coupled with the name of a particular person as the principal scientist, and are for research in the biological and the physical sciences, and also for the support of studies and conferences on science, the exchange of scientific information, the compilation of scientific personnel information, and travel by American scientists to international scientific meet. ings. The latest group of awards range in duration from 6 months to 3 years, with an average length of 1.8 years, and include scientific workers and institutions in most of the States of the United States and also Puerto Rico and Great Britain.

\section{"Gmelins Handbuch der Anorganischen Chemie"}

THe publishers of "Gmelins Handbuch der Anorganischen Chemie", a standard work of international reputation, have announced that an increase in price is unavoidable and will take place immediately. It is pointed out that the preparation of such a work requires the services of a large number of highly qualified specialists, that it covers a much larger range of literature than the corresponding work dealing with organic chemistry, the well-known "Beilstein", and yet reaches a smaller number of purchasers. The proceeds from sales at the old prices covered only about a fifth of the production costs. The step of increasing the price was taken only after most careful consideration of possible alternatives and after adequate consultation. The new prices can be obtained from Verlag Chemie, G.m.b.H., Weinheim, Bergstrasse.

\section{Announcements}

Dr. F. P. Bowden, reader in physical chemistry in the University of Cambridge and head of the Research Laboratory for the Physics and Chemistry of Surfaces, has been awarded the Redwood Medal of the Institute of Petroleum. Prior to the presentation of the Medal, Dr. Bowden delivered an address on "The Friction of Solids".

Str Watrace Akers, director of research, Imperial Chemical Industries, Ltd., has been elected president of the International Institute for the Conservation of Museum Objects in succession to Mr. G. L. Stout, director of the Worcester Art Gallery, U.S.A.

THE British Oxygen Co., Ltd., has appointed Dr. P. H. Sykes, general manager (research and development), to the board of directors, and Dr. N. Booth to be general manager following Dr. Sykes.

THE Medical Research Council announces that the Wernher Research Unit on Deafness, supported from funds made available to the Council by the Alexander Pigott Wernher Trust, has been transferred from the Institute of Laryngology and Otology, Golden Square, London, W.C.1, to King's College Hospital Medical School, London, S.E.5, by arrangement with the Council of the School. Mr. Terence Cawthorne will act as honorary clinical director, and Dr. T. S. Littler continues to be director of the Unit.

Erratum. In the communication entitled "Thelytokous Parthenogenesis . . . in the Desert Locust" (Nature, December 19, p. 1153), the figures in line 4 of Tables 2 and 3 should be in line with ' $F$ ' Parthenogenetically' and not in line with 'Controls', which refers to the egg-pods and hoppers produced sexually. 